\title{
Determinants of Foreign Direct Investments: Dynamic Panel Data Evidence
}

\author{
Mahmut Erdogan ${ }^{1} \&$ Mustafa Unver ${ }^{2}$ \\ ${ }^{1}$ Faculty of Economics and Administrative Sciences, Department of Business Administration, Gümüşhane \\ University, Gümüşhane, Turkey \\ ${ }^{2}$ Faculty of Economics and Administrative Sciences, Department of Economics, Gümüşhane University, \\ Gümüşhane, Turkey
}

Correspondence: Mustafa Unver, Department of Economics, Faculty of Economics and Administrative Sciences, Gümüşhane University, 29100 Gümüşhane, Turkey. E-mail: mustafaunver@gumushane.edu.tr

Received: February 2, 2015

Accepted: February 22, 2015

Online Published: April 25, 2015

doi:10.5539/ijef.v7n5p82

URL: http://dx.doi.org/10.5539/ijef.v7n5p82

\begin{abstract}
This paper examines the determinants of foreign direct investment (FDI) for 88 countries in the 1985-2011 period, using a static and dynamic panel data analysis. The results show that urbanization rate, the ratio of population over the age of 65 , social security spending and health spending have a negative and statistically significant impact on FDI, while per capita GDP, GDP growth, market size, inflation rate, unemployment rate, labor force growth, credit to private sector, market capitalization and control of corruption have a statistically significant positive impact on FDI inflows. In addition, financial openness and energy imports to the host nation have both statistically significant negative and positive impacts on FDI inflows.
\end{abstract}

Keywords: economic development, financial depth, foreign direct investment, social variables, panel data analysis

\section{Introduction}

Global FDI flows remain as the most stable and preferred component of external finance over the past decade, despite the financial and economic crises witnessed in the global economy (UNCTAD, 2014). In this regard, researchers have been strongly motivated to search for specific variables to attract FDI inflows, based on the positive effects of FDI on certain variables in the host economies (see also Borensztein, Gregorio, \& Lee, 1998; Zhang, 2001; Konings, 2001; Kambayashi \& Kiyota, 2014). This concern for the determinants of FDI has resulted specifically from the increasing importance of FDI inflows in the economic development of countries. There have been many previous studies with particular focus on identifying the potential determinants of FDI by looking from different perspectives, including macroeconomic, financial, demographic, political and social determinants (see also Scott-Green \& Clegg, 1999; Alsan, Bloom, \& Canning, 2006; Kimino, Saal, \& Driffield, 2007). On the other hand, other examples of previous literature have analyzed empirically how these selected determinants affect FDI at national, regional and global levels (see also Bende-Nabende, Ford, \& Slater, 2001; Busse \& Hefeker, 2007; Birsan \& Buiga, 2009).

The aim of this paper is to explore the determinants of FDI inflows at a global scale, with the intention of providing both policymakers and foreign investors with empirical results in this regard. Conversely, it has two distinguishing features in its comparison of the variations in literature. First, this paper compares two different approaches to panel data analyses, being static and dynamic (Hsiao \& Hsiao, 2004; Naude \& Krugell, 2007); and second, it assesses whether the determinants of FDI may have different results for the three measures of FDI used in literature. For example, while Bijsterbosch and Kolasa (2010) use gross FDI inflows as a share of value added, Büthe and Milner (2008) and Singh and Jun (1995) included inward FDI stocks as a percentage of GDP and FDI inflows as a percentage of GDP, respectively. We also explain here how these determinants influence FDI inflows by submitting a comprehensive review of existing literature. The most significant measures of the determinants of FDI inflows take into account GDP per capita, GDP growth, market size, market capitalization, secondary school enrollment ratio, labor force growth, over 65 population share, urbanization rate, energy import, financial openness, domestic credit to private sector, corruption, regulatory quality, political stability, social security spending, education spending and health spending. 
This paper is organized as follows. Section 2 discusses the findings of empirical literature on the determinants of FDI; while Section 3 describes the data and methodology used in the paper. The empirical results are presented in Section 4, and conclusions are drawn in Section 5.

\section{Review of Literature}

The empirical variables used in this paper have been adopted from previous literature on the determinants of FDI, and in this section we provide a substantial overview of this literature. There have been a number of studies discussing the relationships between economic, financial, demographic, political and social indicators and FDI inflows.

In our paper, economic indicators have been correlated with GDP per capita, growth of GDP, market size, inflation rate, unemployment rate, growth of labor force and energy import in the host country. First of all, most papers attempted to examine the effects of GDP per capita and growth of GDP on FDI inflows to indicate the economic potential of the host economy. For instance, Büthe and Milner (2008) cite the percentage change in the country's real GDP and the log of per capita GDP as traditional determinants of FDI inflows. Estimates indicate that while there was a statistically significant positive coefficient between GDP growth and FDI inflows, the per capita GDP figures were not statistically significant. Furthermore, Bilgili, Tülüce and Doğan (2012) analyzed the major determinants of FDI with quarterly data set of Turkey for the 1988-2010 period, and recorded a positive and statistically significant coefficient on GDP growth rate. In contrast, Asiedu (2002) suggests that a connection exists between real GDP per capita and FDI inflows in sub-Saharan Africa (SSA) and non-SSA countries. This paper found a negative relationship between the two variables in the SSA, but a positive and statistically significant relationship in non-SSA. While domestic markets need to increase production to obtain more profit, foreign investors expect to find a favorable investment environment. In this regard, the existence of potential for market growth implies that high economic growth supports FDI inflows due to an increase in income and consumption effects (Noorbakhsh, Paloni, \& Youssef, 2001, p. 1597) (see also Braga Nonnenberg, \& Cardoso Mendonca, 2004; Dornean, Işan, \& Oanea, 2012; Hecock \& Jepsen, 2013).

Another important economic variable affecting FDI inflows is market size. The empirical relationship between market size and FDI is a general field of interest in FDI literature, with FDI inflow contributing to local markets by market size and market growth (Demirhan \& Masca, 2008, p. 357). The reason for this is that a larger market size, usually measured by in terms of GDP, GDP per capita and the log of the country's population, is thought to lead to increased FDI inflows (Büthe \& Milner, 2008, p. 748; Martinez \& Allard, 2009, p. 87; Vijayakumar, Perumal, \& Rao, 2010, p. 5). Market size has been described as a proxy for product demand, potential growth and production volume, and so it can be expected that there a positive relationship exists between market size and FDI inflows, owing to the greater expected profitability (Bevan \& Estrin, 2004, p. 778; Dornean et al., 2012, p. 1014). That said, despite the positively significant relationships identified in numerous studies, including those of Bevan and Estrin (2004), Demirhan and Masca (2008), Wahid, Sawkut and Seetanah (2009), Ranjan and Agrawal (2011), Khachoo and Khan (2012) and Chan, Hou, Li and Mountain (2014), the papers of Gani (2007) and Büthe and Milner (2008) suggested a negatively significant relationship.

On the other hand, there is both theoretical and empirical evidence indicating that many countries have been forced to reach stable economic conditions. For example, some papers argue that inflation, especially when stable and low, plays an important role in stimulating FDI, the main reason being that a high inflation rate will emerge demand contractionary pressure, and so foreign company profits composed of income generation opportunities will be affected adversely (Gedik, 2013, p. 124). FDI inflows in this respect are associated closely with low inflation rate, which implies economic stability. In other words, the lower the inflation rate, the greater the increase in the FDI inflows (Demirhan \& Masca, 2008, p. 366). While Braga Nonnenberg and Cardoso Mendonca (2004), Asiedu (2006), Busse and Hefeker (2007), Demirhan and Masca (2008) and Ranjan and Agrawal (2011) all found a significant negative relationship between inflation and FDI, while Asiedu (2002) and Gedik (2013) found no statistically significant relationship among them.

The unemployment rate, as an economic indicator, is used to measure labor cost. For example, Cassou (1997) includes the unemployment rate in his determinants of FDI. The results of this paper indicate that unemployment rate has a negative significant effect on FDI inflows; in other words, when unemployment rate in recessionary times is high, FDI inflows will be lower due to the low level of profit margins. On the other hand, all types of investment depend heavily on labor costs, in that they constitute the greatest share of production costs. In this regard, for an investor it is important to recognise that the unemployment rate influences labor cost due to the associated labor market competition. Consequently, a high unemployment rate can suggest profit opportunities for production in host countries (Janicki \& Wunnava, 2004, p. 506). Coughlin, Terza and Arromdee (1991) and 
Boudier-Bensebaa (2005) also recorded significantly positive results, while the study of Woodward (1992) identified significantly negative results and the study of Voyer and Beamish (2004) recorded insignificant results.

Furthermore, considering the concept of the growth rate of the labor force, the availability of labor affects labor costs to a significant level, in that an abundance of labor naturally results in low labor costs associated with productivity (Noorbakhsh et al., 2001, p. 1598). Although previous empirical papers by Voyer and Beamish (2004) and Ranjan and Agrawal (2011) recorded no statistically significant results, Noorbakhsh et al. (2001) identified a positively and statistically significant relationship between the growth rate of the labor force and FDI inflows. Some papers have used the labor cost variable as a determinant of FDI, in that low labor costs can be a substantial determining factor in the investment decisions of both domestic and foreign investors. Low labor costs resulting from high population growth in developing countries has been one of most important factors influencing FDI inflows. In this regard, they are normally encouraged to invest in areas of investment where wages are subnormal. For foreign investors, it also ensures competitiveness in reaching one's objective in terms of the market share (Gedik, 2013, p. 123). In the meantime, low wage levels may mean two different approaches to foreign investors, being efficiency-seeking and market-seeking. The first of these implies that low labor cost might increase the capacity for competitiveness, while the second may lead foreign investors to have strong market expectations for the sale of produced goods. Ultimately, lower labor costs attract efficiency-seeking investors, as market-seeking investors prefer host countries in which the markets are characterized by high and rising wages (Estrin \& Uvalic, 2014, p. 298). Wahid et al. (2009), Khachoo and Khan (2012) and Gedik (2013) found that labor cost was a negatively significant factor in determining FDI inflows.

Another indicator that has been used to clarify such characteristics as labor cost, quality of labor force and productivity is the secondary school enrollment variable, implying that the human capital in an economy can be used as a proxy for the flow of investment in human capital (Noorbakhsh et al., 2001, p. 1597). Nevertheless, foreign direct investors tend to focus not only on the labor costs in host country, but also on the quality of the labor force, in that a well-educated labor market may provide more profitable economic activity and be easily trained in the use of new technologies. In this regard, human capital can be used as a determinant of accessibility to skilled labor, which is an important feature in attracting foreign investors (Wahid et al., 2009, p. 6). A positive and statistically significant relationship has been identified by Noorbakhsh et al. (2001), Braga Nonnenberg and Cardoso Mendonca (2004), Egger and Winner (2005) and Wahid et al. (2009), while in contrast, Hecock and Jepsen (2013) found no empirical evidence of the effect of secondary school enrollment on FDI inflows.

Finally, a useful economic variable that may contribute to increased FDI inflows is energy imports for the production of goods and services. If a country is dependent on energy from abroad, it will generally come at a high cost. In this regard, the availability of energy is a strategic determinant of production costs, and is also necessary to reach effective industrial targets and to solve production problems (Noorbakhsh et al., 2001, p. 1598). Braga Nonnenberg and Cardoso Mendonca (2004, p. 8) examined the effect of energy consumption on location decision of FDI inflows, based on a study of 33 host countries from 1975-2000. In their paper, energy consumption was measured as per capita energy consumption, which indicates the degree of development of the industrial structure, with data collected from WDI (World Development Indicators). According to their results, energy consumption maintains a negatively and statistically significant relationship with FDI inflows, although they anticipated a positive empirical relationship among them (see also Noorbakhsh et al., 2001; Braga Nonnenberg, \& Mendonca, 2004).

Having explained the economic determinants of FDI, we can now interpret the financial indicators within the host country. Various studies have attempted to explain the relationship between financial variables and FDI inflows. The financial variables addressed here will be, in turn, financial openness, credit to private sector and market capitalization. Recently, studies of financial openness or capital controls have used the KAOPEN index developed by Chinn and Ito (2002), which helps in the measurement of the intensity of capital controls (Chinn \& Ito, 2006; Arestis \& Caner, 2009; Grieco, Gelpi, \& Warren, 2009). Asiedu and Lien (2004), on the other hand, investigated the effect of capital control policies on FDI, excluding the KAOPEN index, and mention that FDI may be decreased through capital controls, and therefore when the capital account is open in the host country, FDI inflows will be attracted there (see also Büthe \& Milner, 2008). There have also been a number of papers assessing the role of the credit market on FDI inflows. For example, Noorbakhsh et al., (2001, p. 1598) used the credits to the private sector as a percentage of GDP variable rather than financial depth. Bank credits to private sector as a measure of the depth of a financial system in a comparison with the public sector is a satisfactory sign of financial development, in that the private sector is more likely to make an efficient utilization of financial resources than the public sector (Ang, 2009, p. 1597) (see also Noorbakhsh et al., 2001; Ang, 2008). Some papers use other variables as a proxy for financial factors determining FDI inflows. While arguments examine 
the relationship between stock markets and FDI outflows and inflows (Dahlquist \& Robertsson, 2001; Chiou, Hung, \& Shu, 2013), others have embodied the market capitalization variable, as a ratio of stock market capitalization to GDP, to express the importance of financial deepening and market development (Durham, 2004; Di Giovanni, 2005).

Previous researches into FDI inflows have examined the effect of the demographic variables used in the empirical section of this paper, such as the urbanization rate and the share of population aged 65 and over. For example, low levels in urbanization rate for Brazil, India and South Africa will positively continue for future perspectives. In these economies, the share of population of working age will tend to grow by 2050, while China and Russia have worsening risks for this age group. In short, countries with a low urbanization rate may see low labor costs in the future; and furthermore, a low urbanization ratio may support a falling working age ratio through the migration of the unemployed rural workforce to urban areas in countries like China, where the urbanization rate is low (Vijayakumar et al., 2010, pp. 2-3). FDI inflows tend to come to the urbanized areas in China as a result of the agglomeration effect, which provides such advantages as the rapid spread of knowledge and economies of scale and scope (Wei, Liu, Parker, \& Vaidya, 1999, p. 864) (see also He, 2002; Chen, 2009; Fan, Morck, Xu, \& Yeung, 2009; Hecock \& Jepsen, 2013).

A dominant driver of FDI inflows can be found in an analysis of the political landscape, referring to corruption, regulatory quality and the level of political stability or instability. Previous literature includes many studies analyzing the relationship between corruption and FDI, revealing that that corruption and the institutional environment of a host country are important determinants of FDI location choice (Egger \& Winner, 2005, p. 933). The corruption variable, as a measure of institutional quality, shows the level of nepotism, excessive patronage and bribery in the political system (Asiedu, 2006, p. 69), although there are different empirical results, both positive and negative, indicating the effect of corruption on FDI inflows. While Egger and Winner (2005) and Busse and Hefeker (2007) make positive and statistically significant estimates, Smarzynska and Wei (2000), Voyer and Beamish (2004), Asiedu (2006), Gani (2007), Hecock and Jepsen (2013) came up with negative and statistically significant results. According to the Worldwide Governance Indicators, regulatory quality, as another political variable, is comprehensively identified as the sensation that the power of the government is able to adopt credible policies in the presence of regulations, and thus also contributes private sector development (see also Rammal \& Zurbruegg, 2006; Gani, 2007). Finally, the political instability variable, or how the host country is evaluated in terms of its political and institutional environment, has emerged as an important indicator for the entry of multinational corporations (Wahid et al., 2009, p. 6) (see also Li \& Resnick, 2003; Zhao, 2003; Asiedu \& Lien, 2004; Asiedu, 2006; Büthe \& Milner, 2008; Wahid et al., 2009; Gedik, 2013 for negative and significant results; Asiedu, 2002; Demirhan \& Masca, 2008 for insignificant results).

From the perspective of investors, there is strong empirical evidence in literature that investments in developing countries are promoted through appropriate policies, in particular, through very high education spending, but political leaders consider that social spending should be deducted for social programs because there is no any contribution of these resources for investors. It is implied, therefore, that leaders should fund better social investment programs to attract FDI from abroad (Hecock \& Jepsen, 2013, p. 157). As an example of this funding, it is understood that improving the quality of education leads to the generation of a higher quality labor force with better skills, which ensures the reduction of labor costs for investors in all sectors (Hecock \& Jepsen, 2013 , p. 158) (see also Chen, 2009; Hecock \& Jepsen, 2013). Another illustration of this can be seen in the study of Alsan et al. (2006) of the effect of population health on gross inflows of FDI for 74 industrialized and developing countries between 1980 and 2000, whose findings, consistent with literature, showed that rising life expectancy increases FDI inflows in developing countries (see also Hecock \& Jepsen, 2013).

\section{Data and Methodology}

In an attempt to analyze the determinants of FDI, 1,929 observations from 88 countries related to the 1985-2011 period were garnered from the WDI. In this study, three different dependent variables are used to represent FDI, p. First is fdigdp, referring to the ratio of FDI (\%) within GDP, following the study of Hecock and Jepsen (2013); second is fdiva, representing FDI value added, following Cipollina, Giovannetti, Pietrovito and Pozzolo (2012); and third is fdinward, referring to the amount of FDI transferred from one country to another within a specified year, following Estrin and Uvalic (2014).

The explanatory variable is lpcgdp, representing the log value of per capita GDP to control for economic development level. In order to control for economic development, we use the gdpg variable, representing the percentage of change in the country's GDP. Furthermore, we used the marketsize variable to represent the logarithmic value of the country population to control for market size of host country, and the inflation variable 
as a proxy for economic stability. The unemployment variable is included another indicator of labor cost while the laborfg variable, which is an indicator for labor growth rate, measures labor presence rather than labor costs, and given that as growth rate increases, labor costs decrease, it can be used for an indicator for labor costs as well. We used the enrol variable to represent secondary school enrollment ratio to show the impact of human capital on investments, quality of labor force and labor cost for productivity, and energy is one of the main infrastructure components when considering a location in which to invest, with investors choosing locations with cheaper energy resources so as to decrease manufacturing costs. In this regard, this study adopts the energy variable as a production cost, defining the presence of energy, as ratio of the net energy import by dividing energy use after subtracting energy production from energy use. The finop variable, formed by the KAOPEN index, as an indicator of the openness of the country's capital account, representing financial openness and also financial freedom is an important factor in the sustainability of capital flow to developing countries; hence, to define the depth of the financial sector, private sector credits are used, defined by the creps variable; and the markcap variable, defining capital market development, is represented by the ratio of the outstanding stock value to GDP. The urban variable shows the rate of urbanization; the over65 variable represents the ratio of population over the age of 65 within total. The socialsec variable represents the ratio of social security expenditures to GDP; educ shows the ratio of education expenditures to GDP; the health variable shows the ratio of health expenditures to GDP. FDI is affected by both economic and political variables. Corruption, regulations and political stability in an invested country fall among these variables. The level of corruption, as a measure of the rate of corruption in a country, is scored in a range of 1 and 10, with higher values referring to a lower rate of corruption. The regul variable refers to governments' skill in designing and executing regulations in support of the private sector; with higher values implying better applications, and lower values indicating poor applications. The polstab variable shows the perception of potential political instability, and is sourced from World Bank Worldwide Governance Indicators.

This study adopts both static and dynamic panel data methods. The following equation (1) was formed using the static panel method.

$$
F D I_{i t}=\alpha+\beta_{1} X_{i t}+e_{i t} \text { for } i=1, \ldots, N \text { and } t=2, \ldots, T
$$

Where $F D I_{i t}$ the level of FDI for country $i$ at the time $t$ as percentages of GDP; $X_{i t}$ is a vector of explanatory variables for country $i$ at the timet. There could be a problem using past levels of dependent variable which is correlated with error term in dynamic panel data models. In order to overcome these problems, when first difference equations are calculated, the variability between groups is filtered from dynamic panel data model. In this study, FDI determinants are also analyzed by a dynamic model, as shown in Equation (2):

$$
F D I_{i t}=\alpha F D I_{i t-1}+\beta_{1} X_{i t}+\beta_{2} X_{i t-1}+\eta_{i}+v_{i t} \text { for } i=1, \ldots, N \text { and } t=2, \ldots, T
$$

Where, $e_{i t}=\eta_{i}+v_{i t}$ is the usual 'fixed effects' decomposition of the error term. $F D I_{i t-1}$ is the ratio of net foreign direct investments to GDP in country $i$ at the time $t-1$. $X_{i t-1}$ shows the control variables in a country $i$ at the time $t-1$.

\section{Empirical Findings}

The empirical analysis of this study is divided into two parts. The first part looks at the fixed effect results of FDI, while the second analyses the GMM system results of FDI. A fixed effect panel regression has been adopted in previous studies (Tintin, 2013; Dornean et al., 2012; Villaverde \& Maza, 2012). Table 1 shows the results in which fdigdp was used as a dependent variable. Following Büthe and Milner (2008), we developed Model 1, which included market size, economic growth and economic development, as well as financial openness, private sector credits and secondary school enrollment. In line with our expectations and economic theory, the lag of lpcgdp variable is found to be positive and statistically significant at $1 \%$ level. This empirical finding supports Parletun and Thede (2008); Ang (2008); Demirhan and Masca (2008); and Vijayakumar et al.'s (2010)'s results, implying that economic development encourages FDI into an economy, and that GDP has a significant positive effect on FDI inflows. In Table 2, where FDI value added is used as a dependent variable, we find a positive significant relation, while in Table 3, usage of fdinward as a dependent variable did not show significant statistically powerful evidence.

The gdpg variable had positive and statistically significant coefficients in all models, as shown in Table 1, Table 2 and Table 3. As fast growing economies will have more opportunities for gain than those that are slow growing, in that they will attract more FDI. This empirical finding proves that an economic growth rate that is realized on previous terms is an important factor in attracting more FDI, which is very sensitive to economic growth. The findings related to economic growth are similar to the results from Noorbakhsh et al. (2001). 
FDI realized in previous years is one of the important components of further FDI. In all models, the lag of FDI variable is found to be positive and statistically significant with FDI. In this regard, FDI realized in previous years increases the current level, and this finding supports those of Noorbakhsh et al. (2001) and Hecock and Jepsen (2013). Our empirical findings for related to financial openness on FDI are rather controversial. In Table 1 we found that it has a positive effect on FDI, while the opposite was true in Table 3, in which it is found that it impacts FDI negatively. In contrast, marketsize variable is positive and statistically significant only in Model 1 in Table 1, which indicates that economies with low labor costs attract more FDI.

Table 1. The determinants of foreign direct investments

\begin{tabular}{|c|c|c|c|c|}
\hline Dependent Variable & (1) & (2) & (3) & (4) \\
\hline Fdigdp & Fixed Effects & Fixed Effects & Fixed Effects & Fixed Effects \\
\hline \multirow[t]{2}{*}{ L.lpcgdp } & $3.838 * * *$ & $4.819^{* *}$ & $5.019 * *$ & $5.091 * *$ \\
\hline & $(1.183)$ & $(2.242)$ & $(2.423)$ & $(2.364)$ \\
\hline \multirow[t]{2}{*}{ L.gdpg } & $13.77 * * *$ & $18.23 * * *$ & $18.72 * * *$ & $18.48 * * *$ \\
\hline & $(2.000)$ & $(3.050)$ & $(3.310)$ & $(3.316)$ \\
\hline \multirow[t]{2}{*}{ L.fdigdp } & $0.374 * * *$ & $0.310 * * *$ & $0.328 * * *$ & $0.328 * * *$ \\
\hline & $(0.0217)$ & $(0.0284)$ & $(0.0303)$ & $(0.0302)$ \\
\hline \multirow[t]{2}{*}{ L.enrol } & -0.739 & -1.442 & -0.648 & -0.809 \\
\hline & $(0.888)$ & (1.609) & $(1.853)$ & (1.834) \\
\hline \multirow[t]{2}{*}{ L.finop } & $0.236^{* * *}$ & 0.115 & 0.138 & 0.144 \\
\hline & $(0.0868)$ & $(0.181)$ & $(0.200)$ & $(0.197)$ \\
\hline \multirow[t]{2}{*}{ L.marketsize } & $4.556^{* *}$ & -2.070 & -0.0737 & 0.599 \\
\hline & (2.136) & $(5.723)$ & (5.859) & $(5.837)$ \\
\hline \multirow[t]{2}{*}{ L.creps } & $0.868 * *$ & 0.911 & 0.898 & 0.960 \\
\hline & $(0.347)$ & $(0.567)$ & $(0.651)$ & $(0.653)$ \\
\hline \multirow[t]{2}{*}{ Laborfg } & & $15.19^{*}$ & $18.33^{* *}$ & $18.13 * *$ \\
\hline & & $(7.980)$ & (8.824) & (8.796) \\
\hline \multirow[t]{2}{*}{ Corruption } & & $0.461 *$ & & \\
\hline & & $(0.271)$ & & \\
\hline \multirow[t]{2}{*}{ Regul } & & & 0.359 & \\
\hline & & & $(0.667)$ & \\
\hline \multirow[t]{2}{*}{ Polstab } & & & & 0.565 \\
\hline & & & & $(0.488)$ \\
\hline \multirow[t]{2}{*}{ Constant } & $-45.17 * * *$ & -3.369 & -16.83 & -21.64 \\
\hline & $(14.13)$ & (38.56) & (38.84) & $(38.88)$ \\
\hline Observations & 1,929 & 1,209 & 1,093 & 1,093 \\
\hline R-squared & 0.246 & 0.154 & 0.167 & 0.168 \\
\hline Number of id & 88 & 88 & 88 & 88 \\
\hline Hausman test & 372.87 & 229.24 & 397.82 & 951.12 \\
\hline
\end{tabular}

Note. Standard errors in parentheses $* * * \mathrm{p}<0.01, * * \mathrm{p}<0.05, * \mathrm{p}<0.1$.

For all models in the three tables, the creps variable coefficient is positive and statistically significant at a $1 \%$ level, and there is empirical evidence that as the private sector credits increase, the economy becomes more attractive for foreign investment. Increase in labor force is one of the factors impacting FDI positively, and in all models in Table 1 and Table 2, except for Model 1 in Table 1, the laborfg variable was found to be positive and statistically significant. 
Table 2. The determinants of foreign direct investments

\begin{tabular}{|c|c|c|c|}
\hline $\begin{array}{l}\text { Dependent Variable } \\
\text { fdiva }\end{array}$ & $\begin{array}{c}(1) \\
\text { Fixed Effects }\end{array}$ & $\begin{array}{c}(2) \\
\text { Fixed Effects }\end{array}$ & $\begin{array}{c}\text { (3) } \\
\text { Fixed Effects }\end{array}$ \\
\hline \multirow[t]{2}{*}{ L.lpcgdp } & 0.0191 & $0.0482 * *$ & $0.0555^{*}$ \\
\hline & $(0.0335)$ & $(0.0208)$ & $(0.0300)$ \\
\hline \multirow[t]{2}{*}{ L.gdpg } & $0.240 * * *$ & $0.183 * * *$ & $0.224 * * *$ \\
\hline & $(0.0485)$ & $(0.0289)$ & $(0.0371)$ \\
\hline \multirow[t]{2}{*}{ L.fdiva } & $0.378^{* * *}$ & $0.362 * * *$ & $0.321 * * *$ \\
\hline & $(0.0368)$ & $(0.0253)$ & $(0.0301)$ \\
\hline \multirow[t]{2}{*}{ L.finop } & -0.000844 & 0.00222 & 0.000996 \\
\hline & $(0.00248)$ & $(0.00141)$ & $(0.00224)$ \\
\hline \multirow[t]{2}{*}{ L.marketsize } & -0.0883 & 0.0526 & -0.0415 \\
\hline & $(0.0843)$ & $(0.0383)$ & $(0.0688)$ \\
\hline \multirow[t]{2}{*}{ creps } & $0.0580 * * *$ & $0.0254 * * *$ & $0.0306^{* * *}$ \\
\hline & $(0.0106)$ & $(0.00522)$ & $(0.00702)$ \\
\hline \multirow[t]{2}{*}{ laborfg } & 0.185 & $0.121 *$ & $0.169^{*}$ \\
\hline & $(0.117)$ & $(0.0711)$ & $(0.0970)$ \\
\hline \multirow[t]{2}{*}{ socialsec } & $-0.00757^{* *}$ & & \\
\hline & $(0.00371)$ & & \\
\hline \multirow[t]{2}{*}{ over65 } & & $-0.269^{*}$ & $-0.507 * *$ \\
\hline & & $(0.147)$ & $(0.220)$ \\
\hline \multirow[t]{2}{*}{ corruption } & & & $0.00790 * *$ \\
\hline & & & $(0.00330)$ \\
\hline \multirow[t]{2}{*}{ Constant } & 0.563 & $-0.527 * *$ & 0.0982 \\
\hline & $(0.575)$ & $(0.253)$ & $(0.468)$ \\
\hline Observations & 724 & 1,505 & 1,108 \\
\hline R-squared & 0.246 & 0.231 & 0.178 \\
\hline Number of id & 54 & 82 & 82 \\
\hline Hausman test & 161.69 & 325.60 & 392.64 \\
\hline
\end{tabular}

Note. Standard errors in parentheses $* * * \mathrm{p}<0.01, * * \mathrm{p}<0.05, * \mathrm{p}<0.1$.

There is a positive statistically significant relationship between the corruption index and FDI. Economies with higher corruption attract less FDI, and this empirical finding is in line with Alsan et al.'s (2006) finding that the type or means of corruption impacts the economy. These economic variables explain about $24 \%$ of the changes in variance of FDI, and in addition, the urban variable is found to be negatively statistically significant in Model 2 in Table 3. In this regard, an increase in qualified labor alongside increased urbanization results in a decrease in FDI.

The socialsec variable in Table 2 has a negative and statistically significant coefficient. Economies with high social security expenditures attract less FDI, just as economies with an older population attract less FDI as well (Table 1 and 2). There is also evidence that less FDI is made in economies with high health expenditures (Table 3). On the other hand, the markcap variable is found to be positive and statistically significant at a $1 \%$ level, which makes a developed market capital economy more attractive for FDI (Table 3). The energy variable coefficient is found to be positive and statistically significant, and as energy usage increases, economies attract more FDI. 
Table 3. The determinants of foreign direct investments

\begin{tabular}{|c|c|c|}
\hline $\begin{array}{l}\text { Depenedent Variable } \\
\text { fdinward }\end{array}$ & $\begin{array}{c}(1) \\
\text { Fixed Effects }\end{array}$ & $\begin{array}{c}(2) \\
\text { Fixed Effects }\end{array}$ \\
\hline \multirow[t]{2}{*}{ L.lpcgdp } & 0.125 & -0.875 \\
\hline & $(3.763)$ & $(4.153)$ \\
\hline \multirow[t]{2}{*}{ L.gdpg } & $21.65^{* * *}$ & $19.54 * * *$ \\
\hline & $(4.657)$ & $(4.679)$ \\
\hline \multirow[t]{2}{*}{ L.fdinward } & $0.336 * * *$ & $0.309^{* * *}$ \\
\hline & $(0.0400)$ & $(0.0401)$ \\
\hline \multirow[t]{2}{*}{ L.finop } & $-0.625 * * *$ & $-0.594 * *$ \\
\hline & $(0.241)$ & $(0.238)$ \\
\hline \multirow[t]{2}{*}{ L.marketsize } & 2.063 & 7.471 \\
\hline & $(11.73)$ & $(11.68)$ \\
\hline \multirow[t]{2}{*}{ creps } & $4.087 * * *$ & $4.479 * * *$ \\
\hline & $(0.925)$ & $(0.910)$ \\
\hline \multirow[t]{2}{*}{ urban } & -18.78 & $-25.70^{*}$ \\
\hline & $(12.61)$ & $(14.04)$ \\
\hline \multirow[t]{2}{*}{ socialsec } & -0.178 & 0.556 \\
\hline & $(0.393)$ & $(0.460)$ \\
\hline \multirow[t]{2}{*}{ educ } & 0.285 & 0.384 \\
\hline & $(0.336)$ & $(0.333)$ \\
\hline \multirow[t]{2}{*}{ health } & & $-0.810^{* * *}$ \\
\hline & & $(0.256)$ \\
\hline \multirow[t]{2}{*}{ over65 } & & 20.79 \\
\hline & & $(26.64)$ \\
\hline \multirow[t]{2}{*}{ markcap } & $0.0351 * * *$ & $0.0344 * * *$ \\
\hline & $(0.00653)$ & $(0.00647)$ \\
\hline \multirow[t]{2}{*}{ energy } & $1.339^{*}$ & $1.714^{* *}$ \\
\hline & $(0.772)$ & $(0.774)$ \\
\hline \multirow[t]{2}{*}{ enrol } & -2.397 & \\
\hline & $(2.528)$ & \\
\hline \multirow[t]{2}{*}{ Constant } & -1.871 & -32.90 \\
\hline & $(76.61)$ & $(74.78)$ \\
\hline Observations & 487 & 487 \\
\hline R-squared & 0.361 & 0.375 \\
\hline Number of id & 48 & 48 \\
\hline Hausman test & 154.43 & 158.30 \\
\hline
\end{tabular}

Note. Standard errors in parentheses $* * * \mathrm{p}<0.01, * * \mathrm{p}<0.05, * \mathrm{p}<0.1$.

Table 4 summarizes the GMM system estimation results that define FDI factors. A one-year delay in FDI is found to be positive and statistically significant in all models, and this result supports the studies of Walsh and Yu (2010), Blonigen and Piger (2011), and Gedik (2013). Similarly, the gdpg variable is also positive and statistically significant at a $1 \%$ level in Model 2, and this empirical result reinforces the finding that states that countries with increasing economic growth attract more FDI. There is no statistically significant proof of the effect of urbanization on FDI, while the unemployment variable is found to be positive and statistically significant in every model. High unemployment rates decrease labor costs in a country, which will thus attract more FDI. These results support the studies of Walsh and Yu (2010), Ranjan and Agrawal (2011), and Gedik (2013). Unlike in the static models, the marketsize variable is found to be positive and statistically significant in every model-a 1 percent increase in the marketsize variable leads to a greater than $1 \%$ increase in FDI, which shows that foreign investors are very sensitive to market sizing. The corruption variable is positive but not statistically significant in every model, while the over65 variable is negative and statistically significant only in Model 3. Surprisingly, a positive and statistically significant relationship exists between inflation and FDI only in Model 1; and the energy variable is negative and statistically significant at a $10 \%$ level in Model 2 . The lpcgdp variable is positive and statistically significant in Model 3, which has satisfactory supportive statistics. 
Table 4. System GMM results for the determinants of FDI

\begin{tabular}{|c|c|c|c|}
\hline \multirow[b]{2}{*}{ Dynamic } & \multicolumn{2}{|l|}{ (1) } & \multirow{2}{*}{$\begin{array}{c}\text { (3) } \\
\text { GMM System }\end{array}$} \\
\hline & GMM System & GMM System & \\
\hline \multirow[t]{2}{*}{ L.fdigdp } & $1.533 * * *$ & $1.765^{* * *}$ & $1.846^{* * *}$ \\
\hline & $(0.131)$ & $(0.202)$ & $(0.204)$ \\
\hline \multirow[t]{2}{*}{ gdpg } & & $17.62 * * *$ & \\
\hline & & $(6.502)$ & \\
\hline \multirow[t]{2}{*}{ urban } & -1.010 & -0.654 & -3.315 \\
\hline & (1.155) & $(1.425)$ & $(2.210)$ \\
\hline \multirow[t]{2}{*}{ unemployment } & $4.567 * *$ & $4.967 *$ & $11.67 * * *$ \\
\hline & $(2.051)$ & $(2.824)$ & $(3.510)$ \\
\hline \multirow[t]{2}{*}{ marketsize } & $1.256^{* * *}$ & $1.496^{* * *}$ & $1.994 * * *$ \\
\hline & $(0.449)$ & $(0.541)$ & (0.599) \\
\hline \multirow[t]{2}{*}{ corruption } & 0.203 & 0.223 & 0.0962 \\
\hline & $(0.129)$ & $(0.180)$ & $(0.162)$ \\
\hline \multirow[t]{2}{*}{ over65 } & -2.349 & -1.583 & $-16.51 *$ \\
\hline & $(4.008)$ & (6.119) & $(8.288)$ \\
\hline \multirow[t]{2}{*}{ inflation } & $1.269 *$ & 0.906 & 1.116 \\
\hline & (0.699) & (1.998) & $(0.875)$ \\
\hline \multirow[t]{2}{*}{ health } & -0.0171 & 0.0410 & -0.0415 \\
\hline & $(0.0632)$ & $(0.107)$ & $(0.0884)$ \\
\hline \multirow[t]{2}{*}{ creps } & -0.348 & 0.246 & -0.608 \\
\hline & $(0.320)$ & $(0.424)$ & $(0.498)$ \\
\hline \multirow[t]{2}{*}{ enrol } & -0.0380 & -0.432 & -0.882 \\
\hline & $(0.782)$ & $(1.224)$ & $(1.176)$ \\
\hline \multirow[t]{2}{*}{ markcap } & $7.85 \mathrm{e}-05$ & -0.00416 & -0.00584 \\
\hline & $(0.00357)$ & $(0.00502)$ & $(0.00507)$ \\
\hline \multirow[t]{2}{*}{ finop } & 0.00579 & -0.0897 & 0.00995 \\
\hline & $(0.104)$ & $(0.155)$ & $(0.151)$ \\
\hline \multirow[t]{2}{*}{ energy } & -0.144 & $-0.253^{*}$ & -0.108 \\
\hline & $(0.0889)$ & $(0.131)$ & $(0.105)$ \\
\hline \multirow[t]{2}{*}{ lpcgdp } & & & $3.009 * *$ \\
\hline & & & $(1.260)$ \\
\hline \multirow[t]{2}{*}{ Constant } & $-11.33 * * *$ & $-15.24 * * *$ & $-25.15 * * *$ \\
\hline & $(3.756)$ & (4.683) & $(7.122)$ \\
\hline Observations & 1,071 & 987 & 1,064 \\
\hline Number of id & 74 & 73 & 74 \\
\hline $\mathrm{m} 1$ & $-2.76(0.006)$ & $-2.44(0.015)$ & $-2.42(0.016)$ \\
\hline $\mathrm{m} 2$ & $0.56(0.574)$ & $0.55(0.580)$ & $0.52(0.606)$ \\
\hline Sargan & $125.40(0.000)$ & $48.42(0.000)$ & $41.32(0.000)$ \\
\hline Hansen & $3.77(0.287)$ & $1.53(0.466)$ & $1.17(0.558)$ \\
\hline
\end{tabular}

Note. Standard errors in parentheses $* * * \mathrm{p}<0.01, * * \mathrm{p}<0.05, * \mathrm{p}<0.1$.

\section{Conclusion}

Although there have been many studies of indicators of FDI, discussions about the direction of the effects of these indicators have not yet been concluded. Most analyses come up with empirical findings by making estimations that take into account strong internalization problems. This study aims primarily to identify the static and dynamic determinants of FDI, and to this end, the FDI indicators of 88 countries for the 1985-2011 period are analyzed through both static and dynamic panel data methods and the GMM estimation method.

This empirical study investigates three different components of FDI, defined as fdigdp, fdiva and fdinward, and the results show that social security expenditures, health expenditures and corruption levels, which have been overlooked in previous studies, have statistically significant effects on FDI. It is also revealed that FDI is significantly affected by previous FDI levels, and economic growth and development rates. Moreover, the degree of financial openness, market size, private sector credits and labor force growth rates are other important factors 
affecting increases in FDI.

While countries with low corruption levels attract more investments, countries with high social security and health expenditures, which tend to have high levels of urbanization and have older populations, attract less investments. Likewise, the level of development of the capital markets and higher energy utilization are also important factors in attracting more foreign investment.

Policies supporting the inflows of FDI could be speed technologically advanced investments up in the economy. This study claims that policymakers should take into account elevation of barriers restricting the access of foreign investors to the markets. Further studies can replicate this studies analysis using a different sample of data so as to identify if there are some special characteristics of selected countries which may affect the intensity of variables on FDI. However further studies can look for how much government policies could help in inviting FDI to economies. Also what can governments do to attract more FDI? is an important question for further research.

\section{References}

Alsan, M., Bloom, D. E., \& Canning, D. (2006). The Effect of Population Health on Foreign Direct Investment Inflows to Low- and Middle-Income Countries. World Development, 34(4), 613-630. http://dx.doi.org/10.1016/j.worlddev.2005.09.006

Ang, J. B. (2008). Determinants of Foreign Direct Investment in Malaysia. Journal of Policy Modeling, 30(1), 185-189. http://dx.doi.org/10.1016/j.jpolmod.2007.06.014

Ang, J. B. (2009). Financial Development and the FDI-Growth Nexus: The Malaysian Experience. Applied Economics, 41(13), 1595-1601. http://dx.doi.org/10.1080/00036840701222553

Arestis, P., \& Caner, A. (2009). Capital Account Liberalisation and Poverty: How Close is the Link? Cambridge Journal of Economics, 62. http://dx.doi.org/10.1093/cje/bep062

Asiedu, E. (2002). On The Determinants of Foreign Direct Investment to Developing Countries: Is Africa Different? World Development, 30(1), 107-119. http://dx.doi.org/10.1016/S0305-750X(01)00100-0

Asiedu, E. (2006). Foreign Direct Investment in Africa: The Role of Natural Resources, Market Size, Government Policy, Institutions and Political Instability. The World Economy, 29(1), 63-77. http://dx.doi.org/10.1111/j.1467-9701.2006.00758.x

Asiedu, E., \& Lien, D. (2004). Capital Controls and Foreign Direct Investment. World Development, 32(3), 479-490. http://dx.doi.org/10.1016/j.worlddev.2003.06.016

Bende-Nabende, A., Ford, J., \& Slater, J. (2001). FDI, Regional Economic İntegration and Endogenous Growth: Some Evidence from Southeast Asia. Pacific Economic Review, 6(3), 383-399. http://dx.doi.org/10.1111/1468-0106.00140

Bevan, A. A., \& Estrin, S. (2004). The Determinants of Foreign Direct Investment into European Transition Economies. Journal of Comparative Economics, 32(4), 775-787. http://dx.doi.org/10.1016/j.jce.2004.08.006

Bijsterbosch, M., \& Kolasa, M. (2010). FDI and Productivity Convergence in Central and Eastern Europe: An Industry-Level Investigation. Review of World Economics, 145(4), 689-712. http://dx.doi.org/10.1007/s10290-009-0036-z

Bilgili, F., Tülüce, N. S. H., \& Doğan, İ. (2012). The Determinants of FDI in Turkey: A Markov Regime-Switching Approach. Economic Modelling, 29(4), 1161-1169. http://dx.doi.org/10.1016/j.econmod.2012.04.009

Birsan, M., \& Buiga, A. (2009). FDI determinants: Case of Romania. Transition Studies Review, 15(4), 726-736. http://dx.doi.org/10.1007/s11300-008-0033-2

Blonigen, B. A., \& Piger, J. (2011). Determinants of Foreign Direct Investment (No. w16704). National Bureau of Economic Research. http://dx.doi.org/10.3386/w16704

Borensztein, E., De Gregorio, J., \& Lee, J. W. (1998). How Does Foreign Direct Investment Affect Economic Growth? Journal of International Economics, 45(1), 115-135. http://dx.doi.org/10.1016/S0022-1996(97)00033-0

Boudier-Bensebaa, F. (2005). Agglomeration Economies and Location Choice: Foreign Direct Investment in Hungary. Economics of Transition, 13(4), 605-628. http://dx.doi.org/10.1111/j.0967-0750.2005.00234.x

Braga Nonnenberg, M., \& Cardoso Mendonca, M. (2004). The Determinants of Direct Foreign Investment in Developing Countries. http://dx.doi.org/10.2139/ssrn.525462 
Busse, M., \& Hefeker, C. (2007). Political Risk, Institutions and Foreign Direct Investment. European Journal of Political Economy, 23(2), 397-415. http://dx.doi.org/10.1016/j.ejpoleco.2006.02.003

Büthe, T., \& Milner, H. V. (2008). The Politics of Foreign Direct Investment Into Developing Countries: Increasing FDI Through International Trade Agreements? American Journal of Political Science, 52(4), 741-762. http://dx.doi.org/ 10.1111/j.1540-5907.2008.00340.x

Cassou, S. P. (1997). The Link between Tax Rates and Foreign Direct Investment. Applied Economics, 29(10), 1295-1301. http://dx.doi.org/10.1080/00036849700000019

Chan, M. W., Hou, K., Li, X., \& Mountain, D. C. (2014). Foreign Direct Investment and Its Determinants: A Regional Panel Causality Analysis. The Quarterly Review of Economics and Finance, 54(4), 579-589. http://dx.doi.org/10.1016/j.qref.2013.07.004

Chen, Y. (2009). Agglomeration and Location of Foreign Direct Investment: The Case of China. China Economic Review, 20(3), 549-557. http://dx.doi.org/10.1016/j.chieco.2009.03.005

Chinn, M. D., \& Ito, H. (2002). Capital Account Liberalization, Institutions And Financial Development: Cross Country Evidence (No. w8967). National Bureau of Economic Research. http://dx.doi.org/10.3386/w8967

Chinn, M. D., \& Ito, H. (2006). What Matters for Financial Development? Capital Controls, Institutions, and Interactions. Journal of Development $\quad$ Economics, $163-192$. http://dx.doi.org/10.1016/j.jdeveco.2005.05.010

Chiou, C. L., Hung, M. W., \& Shu, P. G. (2013). Foreign Direct Investment in Emerging Markets: Bondholders' Perspective. Emerging Markets Finance and Trade, 49, 5-16. http://dx.doi.org/10.2753/REE1540-496X4905S401

Cipollina, M., Giovannetti, G., Pietrovito, F., \& Pozzolo, A. F. (2012). FDI and Growth: What Cross-country Industry Data Say. The World Economy, 35(11), 1599-1629. http://dx.doi.org/10.1111/j.1467-9701.2012.01478.x

Coughlin, C. C., Terza, J. V., \& Arromdee, V. (1991). State Characteristics and the Location of Foreign Direct Investment within the United States. The Review of Economics and Statistics, 675-683.

Dahlquist, M., \& Robertsson, G. (2001). Direct Foreign Ownership, Institutional Investors, and Firm Characteristics. Journal of Financial Economics, 59(3), 413-440. http://dx.doi.org/10.1016/S0304-405X(00)00092-1

Demirhan, E., \& Masca, M. (2008). Determinants of Foreign Direct Investment Flows to Developing Countries: A Cross-Sectional Analysis. Prague Economic Papers, 4, 356-369.

Di Giovanni, J. (2005). What Drives Capital Flows? The Case of Cross-Border M\&A Activity and Financial Deepening. Journal of International Economics, $127-149$. http://dx.doi.org/10.1016/j.jinteco.2003.11.007

Dornean, A., Işan, V., \& Oanea, D. C. (2012). The Impact of the Recent Global Crisis on Foreign Direct Investment. Evidence from Central and Eastern European Countries. Procedia Economics and Finance, 3, 1012-1017. http://dx.doi.org/10.1016/S2212-5671(12)00266-3

Durham, J. B. (2004). Absorptive Capacity and the Effects of Foreign Direct Investment and Equity Foreign Portfolio Investment on Economic Growth. European Economic Review, 48(2), 285-306. http://dx.doi.org/10.1016/S0014-2921(02)00264-7

Egger, P., \& Winner, H. (2005). Evidence on Corruption as an Incentive for Foreign Direct Investment. European Journal of Political Economy, 21(4), 932-952. http://dx.doi.org/10.1016/j.ejpoleco.2005.01.002

Estrin, S., \& Uvalic, M. (2014). FDI into Transition Economies: Are the Balkans Different? Economics of Transition, 22(2), 281-312. http://dx.doi.org/10.1111/ecot.12040

Fan, J. P., Morck, R., Xu, L. C., \& Yeung, B. (2009). Institutions and Foreign Direct Investment: China versus the Rest of the World. World Development, 37(4), 852-865. http://dx.doi.org/10.1016/j.worlddev.2008.07.016

Gani, A. (2007). Governance and Foreign Direct Investment Links: Evidence from Panel Data Estimations. Applied Economics Letters, 14(10), 753-756. http://dx.doi.org/10.1080/13504850600592598

Gedik, M. A. (2013). Determinants of Foreign Direct Investment for OECD Countries: Evidence from Dynamic Panel Data Analysis. British Journal of Economics, Finance and Management Sciences, 7(2), 119-140.

Grieco, J. M., Gelpi, C. F., \& Warren, T. (2009). When Preferences and Commitments Collide: The Effect of 
Relative Partisan Shifts on International Treaty Compliance. International Organization, 63(2), 341-355. http://dx.doi.org/10.1017/S0020818309090110

He, C. (2002). Information Costs, Agglomeration Economies and the Location of Foreign Direct Investment in China. Regional Studies, 36(9), 1029-1036. http://dx.doi.org/10.1080/0034340022000022530

Hecock, R. D., \& Jepsen, E. M. (2013). Should Countries Engage in a Race to the Bottom? The Effect of Social Spending on FDI. World Development, 44, 156-164. http://dx.doi.org/10.1016/j.worlddev.2012.10.016

Hsiao, F. S., \& Hsiao, M. C. W. (2004). The Chaotic Attractor of Foreign Direct Investment-Why China? A Panel Data Analysis. Journal of Asian Economics, 15(4), 641-670. http://dx.doi.org/10.1016/j.asieco.2004.05.013

Janicki, H. P., \& Wunnava, P. V. (2004). Determinants of Foreign Direct Investment: Empirical Evidence from EU Accession Candidates. $\quad$ Applied $\quad$ Economics, $\quad 36(5), \quad$ 505-509. http://dx.doi.org/10.1080/00036840410001682214

Kambayashi, R., \& Kiyota, K. (2014). Disemployment Caused by Foreign Direct Investment? Multinationals and Japanese Employment. Review of World Economics, 1-28. http://dx.doi.org/10.1007/s10290-014-0205-6

Khachoo, A. Q., \& Khan, M. I. (2012). Determinants of FDI Inflows to Developing Countries: A Panel Data Analysis.

Kimino, S., Saal, D. S., \& Driffield, N. (2007). Macro Determinants of FDI Inflows to Japan: An Analysis of Source Country Characteristics. The World Economy, 30(3), 446-469. http://dx.doi.org/10.1111/j.1467-9701.2007.01001.x

Konings, J. (2001). The Effects of Foreign Direct Investment on Domestic Firms. Economics of Transition, 9(3), 619-633. http://dx.doi.org/ 10.1111/1468-0351.00091

Li, Q., \& Resnick, A. (2003). Reversal of Fortunes: Democratic Institutions and Foreign Direct Investment Inflows to Developing Countries. International Organization, $\quad 57(1), \quad$ 175-211. http://dx.doi.org/10.1017/S0020818303571077

Martinez, C. A., \& Allard, G. (2009). Foreign Direct Investment and Social Policy: The Links in Developing Countries. The Journal of Business in Developing Countries, 11.

Naudé, W. A., \& Krugell, W. F. (2007). Investigating Geography and Institutions as Determinants of Foreign Direct Investment in Africa Using Panel Data. Applied Economics, 39(10), 1223-1233. http://dx.doi.org/10.1080/00036840600567686

Noorbakhsh, F., Paloni, A., \& Youssef, A. (2001). Human Capital and FDI Inflows to Developing Countries: New $\begin{array}{llll}\text { Empirical } \quad \text { Evidence. } & \text { World }\end{array}$ http://dx.doi.org/10.1016/S0305-750X(01)00054-7

Pärletun, J., \& Thede, S. (2008). The Determinants of Foreign Direct Investment: A Regional Analysis with Focus on Belarus. Lund University, 10-16.

Rammal, H. G., \& Zurbruegg, R. (2006). The Impact of Regulatory Quality on Intra-Foreign Direct Investment Flows in the ASEAN Markets. International Business Review, 15(4), 401-414. http://dx.doi.org/10.1016/j.ibusrev.2006.05.001

Ranjan, V., \& Agrawal, G. (2011). FDI Inflow Determinants in BRIC countries: A Panel Data Analysis. International Business Research, 4(4), 255. http://dx.doi.org/10.5539/ibr.v4n4p255

Scott-Green, S., \& Clegg, J. (1999). The Determinants of New FDI Capital Flows into the EC: A Statistical Comparison of the USA and Japan. JCMS: Journal of Common Market Studies, 37(4), 597-616. http://dx.doi.org/10.1111/1468-5965.00198

Singh, H., \& Jun, K. W. (1995). Some New Evidence on Determinants of Foreign Direct Investment in Developing Countries. World Bank Policy Research Working Paper, (1531).

Smarzynska, B. K., \& Wei, S. J. (2000). Corruption and Composition of Foreign Direct Investment: Firm-Level Evidence (No. w7969). National Bureau Of Economic Research. http://dx.doi.org/10.3386/w7969

Tintin, C. (2013). The Determinants of Foreign Direct Investment Inflows in the Central and Eastern European Countries: The Importance of Institutions. Communist and Post-Communist Studies, 46(2), 287-298. http://dx.doi.org/10.1016/j.postcomstud.2013.03.006

United Nations Conference on Trade and Development (UNCTAD). (2014). World Investment Report. UN, New York and Geneva. 
Vijayakumar, N., Perumal, S., \& Rao, K. C. (2010). Determinants of FDI in BRICS Countries: A Panel Analysis. International Journal of Business Science and Applied Management, 5(3), 1-13.

Villaverde, J., \& Maza, A. (2012). Foreign Direct Investment in Spain: Regional Distribution and Determinants. International Business Review, 21(4), 722-733. http://dx.doi.org/10.1016/j.ibusrev.2011.08.004

Voyer, P. A., \& Beamish, P. W. (2004). The Effect of Corruption on Japanese Foreign Direct Investment. Journal of Business Ethics, 50(3), 211-224. http://dx.doi.org/10.1023/B:BUSI.0000024737.57926.bf

Wahid, A. N., Sawkut, R., \& Seetanah, B. (2009). Determinants of Foreign Direct Investments (FDI): Lessons from the African Economies. Journal of Applied Business and Economics, 9(1), 70.

Walsh, M. J. P., \& Yu, J. (2010). Determinants of Foreign Direct Investment: A Sectoral and Institutional Approach (EPub). International Monetary Fund, No. 10-187.

Wei, Y., Liu, X., Parker, D., \& Vaidya, K. (1999). The Regional Distribution of Foreign Direct Investment in China. Regional Studies, 33(9), 857-867. http://dx.doi.org/10.1080/00343409950075498

Woodward, D. P. (1992). Locational Determinants of Japanese Manufacturing Start-ups in the United States. Southern Economic Journal, 690-708.

Zhang, K. H. (2001). How Does Foreign Direct Investment Affect Economic Growth in China? Economics of Transition, 9(3), 679-693. http://dx.doi.org/10.1111/1468-0351.00095

Zhao, H. (2003). Country Factor Differentials as Determinants of FDI Flow to China. Thunderbird International Business Review, 45(2), 149-169. http://dx.doi.org/10.1002/tie.10067

\section{Appendix A. List of Countries}

\begin{tabular}{|c|c|c|c|c|c|}
\hline Countries & Years & Countries & Years & Countries & Years \\
\hline Albania & $1992-2011$ & Greece & $1985-2011$ & Paraguay & $1985-2011$ \\
\hline Algeria & $1985-2011$ & Hong Kong & $1998-2011$ & Peru & $1985-2011$ \\
\hline Argentina & $1985-2011$ & Hungary & $1990-2011$ & Philippines & $1985-2011$ \\
\hline Australia & $1985-2011$ & Iceland & $1985-2011$ & Poland & $1990-2011$ \\
\hline Austria & $1985-2011$ & Indonesia & $1985-2011$ & Portugal & $1985-2011$ \\
\hline Barbados & $1985-2011$ & Iran & $1985-2011$ & Romania & $1990-2011$ \\
\hline Belgium & $1985-2011$ & Ireland & 2000-2011 & Russian Federation & $1992-2011$ \\
\hline Belize & $1985-2011$ & Israel & $1985-2011$ & Serbia & $1997-2011$ \\
\hline Bolivia & $1985-2011$ & Italy & $1985-2011$ & Slovakia & 1993-2011 \\
\hline Brazil & $1985-2011$ & Japan & $1985-2011$ & Slovenia & $1992-2011$ \\
\hline Bulgaria & $1990-2011$ & Jordan & $1985-2011$ & South Africa & $1985-2011$ \\
\hline Canada & $1985-2011$ & Kazakhstan & $1992-2011$ & Spain & $1985-2011$ \\
\hline Chile & $1985-2011$ & Korea Republic & $1985-2011$ & Sri Lanka & $1985-2011$ \\
\hline China & $1985-2011$ & Kuwait & $1995-2011$ & Sudan Republic & $1985-2011$ \\
\hline Colombia & $1985-2011$ & Kyrgyzstan & 1994-2011 & Sweden & $1985-2011$ \\
\hline Costa Rica & $1985-2011$ & Latvia & 1992-2011 & Switzerland & $1985-2011$ \\
\hline Croatia & $1995-2011$ & Lithuania & 1993-2011 & Syrian Arab Republic & $1985-2011$ \\
\hline Cuba & $1985-2011$ & Macedonia & 1994-2011 & Tajikistan & $1992-2011$ \\
\hline Cyprus & $1985-2011$ & Malaysia & $1985-2011$ & Thailand & $1985-2011$ \\
\hline Czech Republic & $1993-2011$ & Malta & $1985-2011$ & Trinidad and Tobago & $1985-2011$ \\
\hline Denmark & $1985-2011$ & Mauritius & $1985-2011$ & Tunisia & $1985-2011$ \\
\hline Ecuador & $1985-2011$ & Mexico & $1985-2011$ & Turkey & $1985-2011$ \\
\hline Egypt & $1985-2011$ & Moldova & $1922-2011$ & Ukraine & 1992-2011 \\
\hline El Salvador & $1990-2011$ & Morocco & $1985-2011$ & United Kingdom & $1985-2011$ \\
\hline Estonia & $1995-2011$ & Netherlands & $1985-2011$ & United States & $1985-2011$ \\
\hline Fiji & $1985-2011$ & New Zealand & 1985-2011 & Uruguay & $1985-2011$ \\
\hline Finland & $1985-2011$ & Nicaragua & $1985-2011$ & Uzbekistan & $1992-2011$ \\
\hline France & $1985-2011$ & Nigeria & $2000-2011$ & Venezuela & $1985-2011$ \\
\hline Georgia & $1997-2011$ & Norway & $1985-2011$ & & \\
\hline Germany & $1985-2011$ & Pakistan & $1985-2011$ & & \\
\hline
\end{tabular}




\section{Appendix B. Definitions and Sources of Variables}

\begin{tabular}{|c|c|c|}
\hline Variable Name & Definition & Source \\
\hline fdigdp & FDI, net inflows ( $\%$ of GDP) & WDI \\
\hline fdiva & FDI inflow (Net inflows, BoP current US\$)/value added at factor cost (current US\$) & WDI \\
\hline lpcgdp & Log of GDP per capita (constant 2005 US\$) & WDI \\
\hline gdpg & Growth of GDP (constant 2005 US\$) & WDI \\
\hline inflation & Consumer prices (annual \% change) & WDI \\
\hline unemployment & Unemployment rate & ILO \\
\hline laborfg & Growth of labor force & WDI \\
\hline enrol & Secondary school enrollment ( $\%$ of gross) & WDI \\
\hline energy & Energy import, (energyuse-energyproduction)/energyuse & WDI \\
\hline urban & Urban population ( $\%$ of total population) & WDI \\
\hline over65 & Population ages 65 and above ( $\%$ of total population) & WDI \\
\hline socialsec & Social security spending ( $\%$ of GDP) & WHO \\
\hline educ & Education spending ( $\%$ of GDP) & WDI \\
\hline health & Health spending ( $\%$ of GDP) & WHO \\
\hline corruption & Control of corruption & WDI \\
\hline regul & Regulatory Quality & WDI \\
\hline polstab & Politic stability and absence of violence/terrorism & WDI \\
\hline
\end{tabular}

\section{Copyrights}

Copyright for this article is retained by the author(s), with first publication rights granted to the journal.

This is an open-access article distributed under the terms and conditions of the Creative Commons Attribution license (http://creativecommons.org/licenses/by/3.0/). 